\title{
Russian industry innovative activity in the process of transition to the digital economy: trends, threats and opportunities
}

\author{
Natalya Pasmurtseva* \\ Ural State University of Economics, 620144, 8 Marta Str., 62, Ekaterinburg, Russia
}

\begin{abstract}
The current changes in the economy made up by the transition to the sixth technological order and the development of the "Fourth industrial revolution" concept, are impossible without the innovative technologies development and implementation. In these circumstances it becomes highly important for the industrial enterprises to implement innovative solutions via the use of modern information and communication technologies. This article reveals the problems of the Russian Federation industrial enterprises innovation implementation in the course of transition to the digital economy. The analysis of the innovation activity indicators and the assessment of the software and information and communication technologies use by the Russian Federation industrial production organizations in 2017-2019 were made according to the Federal State Statistics Service data. From the research results the author identifies positive and negative trends in the innovative industrial development in Russia, and identifies the threats to the industrial production innovative solutions implementation and possible ways to minimize them. For this research the author used such methods as: comparative and logical analysis, system approach, graph and table scientific research methods.
\end{abstract}

\section{Introduction}

Over the past few years, the modern world has been constantly facing serious global challenges, going through which becomes impossible without the active involvement of digital technologies, including the development of various technological platforms and the information infrastructure formation.

Currently, the development of the world economy is unthinkable without the active integration of innovations and industrial production digitalization, which are the basis for the passing to the sixth technological mode. The Russian Federation, along with other countries, is actively involved in the development of the digital economy, which can only be formed by innovative information and communication technologies integration and computerization of industrial enterprises business processes. However, the information sector in the Russian Federation is only 5-7\% of GNP, whereas in the developed countries

${ }^{*}$ Corresponding author: pnn-kufeu@yandex.ru 
this sector can reach 30-40\% of GNP [1]. Moreover, according to the 2016 Global information technologies report, Russia takes only the $41^{\text {st }}$ place in terms of readiness for the digital economy and the 38th in terms of effective implementation of these technologies

Thus, the industrial digitalization undertaken in the framework of the Fourth industrial revolution (Industry 4.0) concept certainly requires taking active steps to ensure industrial enterprises innovation, which makes the problem of building up innovative activity of the Russian Federation industrial manufacturing in the course of economy digitization even more urgent.

The aim of this research is to analyze the main trends in the innovations and digital technologies implementation into the Russian industrial manufacturing, and to identify threats and opportunities of further innovative development and digitalization of the Russian economy.

\section{Innovative activity and the level of digitalization in the Russian Federation industrial production - analysis}

Industry is a priority and budget-forming sector of the Russian economy. According to the Federal State Statistics Service "Rosstat" [3], the national industrial production made a share of $66.5 \%$ in the country's GDP by shipped goods, for 2018, and in 2019 it was $66.1 \%$. Industry is the engine of the economy for many regions, it forms the lion's share of the budget revenue. Large industrial enterprises can be called socially significant and socially responsible economic entities, since they are often city-forming, and influence the social infrastructure of a city or even an entire region.

Despite the high social and economic significance of industrial production sectors for the development of the Russian economy and the growth of its citizens welfare level, the business confidence index, which demonstrates the level of stability of the functioning of industrial enterprises in Russia and is made up from the answers of industrial production managers to questions about the output forecast, balances and demand for it, tends to decrease. Thus, according to Rosstat [3], throughout 2019, the business confidence index fluctuated in values from -2 to +2 , gradually decreasing in 2020 , reaching its critical values from -5 to -10 in the industrial production sector in April-May 2020, depending on the type of economic activity. Moreover, the depreciation rate of fixed assets in industrial manufacturing remains quite high, being at the level of $50.6 \%$ in $2018-2019$, which indicates that they are not sufficiently updated.

The "Forecast for the Russian Federation long-term socio-economic development for the period up to 2030 " notes "...a significant factor determining the industrial complex long term development is the effective integration of national producers into global value chains in the process of forming a new technological mode" [4]. At the same time, the national economy digitalization is impossible without the individual industrial enterprises involvement into this process, and their orientation to the economic activity innovative development model $[5,6]$.

The Federal State Statistics Service official data analysis [3] shows that the indicators of innovation activity for the industrial enterprises have a very unstable dynamics in changing, and are characterized by alternating slight growth or decline. Thus, the level of innovation activity in industrial production tends to decrease in 2019 compared to 2017 and 2018 by $15 \%$ and $3 \%$, respectively. At the same time, the share of organizations implementing technological innovations in industrial production increases from $19.6 \%$ in 2017 to $20.0 \%$ in 2019.

On the one hand the analyzed period of 2017-2019 demonstrates an increase in the volume of shipped innovative industrial goods in 2019 by $5 \%$ compared to 2018 and by $14 \%$ compared to 2017 , but on the other hand their share in the total volume of shipped 
products is reduced from $6.7 \%$ in 2017 to $6.0 \%$ and $6.1 \%$ in 2018 and 2019 , respectively. It should be noted that the share of newly introduced innovations in the total number of innovative products is quite high, but in 2018-2019, compared to 2017, it tends to decrease, which indicates a negative dynamics of industrial production innovative activity in relation to radical innovations (table 1 ).

The innovative activity of industrial enterprises is also shown by such indicators as: the innovation input and industrial production investment in fixed assets. Thus, the indicator of industrial enterprises expenditures on innovations has a positive trend, increasing in the studied period by $4.6 \%$ in 2018 compared to 2017 and by $11 \%$ in 2019 compared to the previous period.

Table 1. Innovative activity indicators for the Russian Federation industrial enterprises in 2017-2019

\begin{tabular}{|l|c|c|c|}
\hline \multicolumn{1}{|c|}{ Indicator } & $\mathbf{2 0 1 7}$ & $\mathbf{2 0 1 8}$ & $\mathbf{2 0 1 9}$ \\
\hline $\begin{array}{l}\text { Goods shipped and works and services performed, } \\
\text { billion roubles }\end{array}$ & 50873 & 61292 & 63167 \\
\hline $\begin{array}{l}\text { Including innovative goods, works, services, billion } \\
\text { roubles. }\end{array}$ & 3403 & 3693 & 3871 \\
\hline Share of innovative goods, works, and services, \% & 6,7 & 6,0 & 6,1 \\
\hline $\begin{array}{l}\text { Innovative goods, works, services newly introduced or } \\
\text { subjected to significant technological changes over the } \\
\text { past three years in the Russian Federation, billion } \\
\text { roubles }\end{array}$ & 2435 & 2392 & 2497 \\
\hline $\begin{array}{l}\text { The share of newly introduced or subjected to } \\
\text { significant technological changes in the total volume of } \\
\text { innovative goods, works, and services over the past } \\
\text { three years, } \%\end{array}$ & 71,5 & 64,8 & 64,5 \\
\hline
\end{tabular}

The indicator of investments into the industrial production organizations fixed assets also shows growth: from 6411 billion roubles in 2017 to 7327.3 billion roubles in 2019 , which in relative dynamics is $7.8 \%$ in 2018 compared to 2017 and $6 \%$ in 2019 compared to the previous period (Fig. 1).

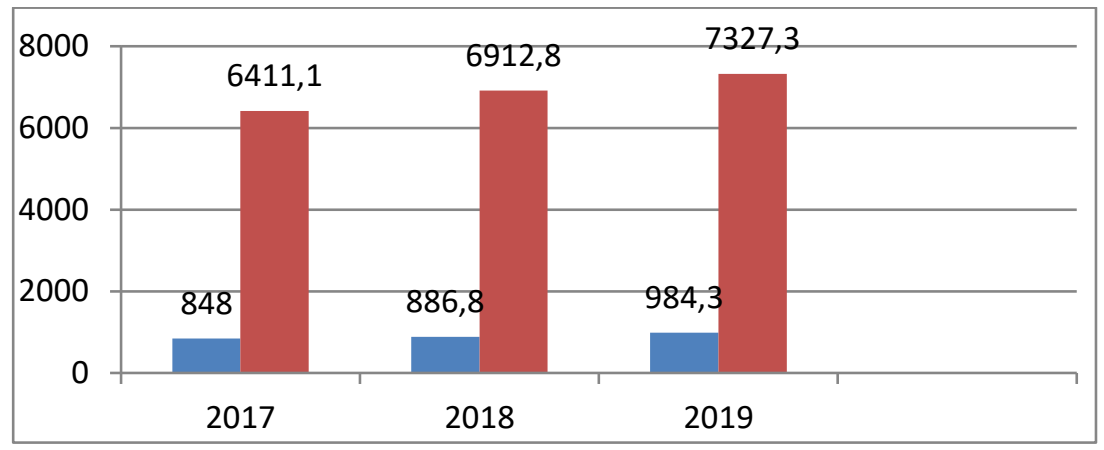

Fig. 1. Changes in innovation expenditures indicators and investments into industrial enterprises fixed assets in 2017-2019, billion roubles

It is impossible to introduce innovations in industrial production sphere without creating high-performing employment. According to Rosstat data [3] there is a steady positive dynamics of their growth in the studied period, especially in the manufacturing sector. Thus, in 2018, the number of efficient jobs in the Russian Federation industrial production increased by $9.8 \%$ compared to 2017 , and in 2019 by $5.8 \%$ compared to the previous period. In particular, the largest increase occurred in the manufacturing sector in 2018 - by $11.6 \%$, and in the water supply and sanitation sector - by $17.6 \%$ in 2019 . 
The Russian industrial enterprises level of digitalization remains very low, and the volume of companies investments is insufficient to increase their competitiveness in the global market. Thus, the share of Russian enterprises investment in digital technologies is $2.2 \%$ of GDP, while in the United States it reached $5 \%$; in European countries - $3.9 \%$; in Brazil - $3.6 \%$ [7].

In order to form and develop the digital economy and increase the level of industrial production digitalization in our country, the project titled " Russian Federation Digital Economy" has been developed and is now being implemented. One of the goals of this scheme is to "increase competitiveness in the global market, both for individual sectors of the Russian economy and the economy in general" [8]. In 2018, Russia took the 46th position in the Global innovation index for the world. The digitalization index, demonstrated by "the level of broadband Internet, cloud services, RFID technologies and ERP systems use, and the business sector organizations involvement in e-Commerce", was 28 in 2017, while the ICT sector contribution to economic development reached 2211 billion rubles, which is $2.7 \%$ of GDP [9].

According to the Russian Federation Federal State Statistics Service and the Ministry for Digital Development, Communications and Mass Media [9], the use of RFID technologies in industrial production organizations in 2018 amounted to $7.8 \%$ of the total number of organizations in the business sector. The index of using software tools "for performing financial calculations in digital form and solving organizational and managerial issues" by industrial enterprises is quite high [9]. Thus in $201860.1 \%$ of industrial organizations used digital form for their financial calculations, and almost the same number of organizations (58.7\%) solved organizational, managerial and economic issues using software. The share of industrial production organizations that provide "access to databases via global information networks" [9] was $27.2 \%$ of the total number of organizations in the business sector.

The index of CRM, ERP, and SCM systems use by industrial production organizations in 2018 is $12 \%, 19.2 \%$, and $5.8 \%$, respectively. However, it is much lower than the indicators of using CRM, ERP, and SCM systems in business sector organizations in the developed countries. For example, in Germany, the use of ERP and CRM systems made $38 \%$ and $49 \%$, respectively, compared to $13 \%$ and $19 \%$ in Russia.

Besides, according to Rosstat [3], the share of technologies and software purchased by industrial organizations increased significantly in the studied period. In 2017 it grew up to $8.9 \%$ compared to 2016 , and in 2018 it was $11.7 \%$ higher than that.

\section{Trends and features in the innovative development of the Russian Federation industrial production in course of transition to the digital economy}

According to the results taken from the innovation activity and level of the Russian Federation industrial complex digitalization analysis, the author formulated the following main positive and negative trends, as well as worked out the features of the Russian industry innovative development in the course of transition to digital economy:

- a large share of industrial production in the Russian GDP;

- decrease in the business confidence index for business managers;

- decrease in the level of industrial enterprises innovation activity in the Russian Federation;

- a growth in the volume of shipped innovative industrial goods in the studied period;

- reduction in the share of innovative products in the total number of goods shipped by industrial enterprises; 
- negative dynamics in the industrial enterprises innovation activity in relation to radical innovations;

- increase in the cost of industrial enterprises innovation;

-increase in the indicator of investments in the industrial production organizations fixed assets;

- strong dynamic growth in high-performance employment in Russian industrial enterprises;

- low level of RFID technologies, CRM, ERP, and SCM systems use by the industrial production organizations;

- a fairly high level of software usage by industrial enterprises;

- a growing number of technologies and software purchased by industrial organizations.

\section{Main threats and opportunities for innovative development and further digitalization of Russian industrial enterprises}

According to the author, the main threats and factors hindering the industrial enterprises innovative development in the digital economy, as well as the opportunities and prospects for further digitalization, can be formulated as follows.

1. Lack of personnel with relevant competencies for the implementation of the innovations and the use of digital technologies. A research [10] shows that the main problems in the digital technologies implementation and development in industrial enterprises are technological incompetence of users (55\%) and low level of involvement and interest of staff (47\%) [10]. To solve the problem it is necessary to "adapt the educational infrastructure to modern market requirements" [11], increase the motivation and interest of staff in the development of digital technologies and the introduction of innovations in their enterprises, and develop new approaches to training. In order to improve the technological competence of specialists, it is necessary to develop and implement schemes for the adaptation of stuff "saved by production computerization and labour productivity growth" [11], as well as for refresher courses and advanced training for the personnel.

2. Lack of funds, high costs and high economic risk of innovation. Besides, despite a slight but steady increase in industrial enterprises fixed assets investment in 2017-2019, there are currently some factors that affect the industrial enterprises investment situation the consequences of the COVID-19 pandemic, the growth of the dollar and Euro rate, increased unemployment level, and a decrease in the standard of living in the population.

3. Insufficient industrial enterprises innovation potential and poor-developed innovation and digital infrastructure. Thus, according to a research $[12,13]$, in terms of digital maturity the majority of Russian industrial enterprises belong to the "digital follower" group (46\%), while only one fifth of enterprises (22\%) are "digital newcomers", introducing innovative digital technologies for the first time, and only $5 \%$ of industrial enterprises can be attributed to the "digital champions" group by actively using the benefits of digitalization to increase their competitiveness.

4. Low level of state support for industrial enterprises innovative activities, including lack of financial support.

5. Insufficient state interaction with the representatives of various industries on issues of innovative development and digitalization. To solve the problem, it is necessary to create special platforms for state authorities and industrial production sectors representatives communication, and develop digital infrastructure.

6. The problem of increasing inequality between regional industrial enterprises, which is in a gap of using information and communication technologies opportunities. In the future, 
"...technological changes will widen the digital gap and make even greater social stratification" [12].

\section{Conclusion}

The transition to digitalization and technological development on the basis of innovative technologies are key factors for the modern industrial enterprises global competitiveness. Despite that the Russian industrial enterprises mostly take positive trends in the innovative development and the use of digital technologies, they fall behind the indicators of developed countries, since the transition to digitalization and active innovations implementation require serious investment, new knowledges, accurate forecasts for the enterprise development, and management technologies improvements. Besides, today flexibility, adaptability, and rapid response to market demands are the key points for the industrial enterprises survival and success. The most important conditions that can increase the level of industry readiness for digitalization and innovative growth, as well as reduce the technology use gap to the developed countries in terms of technology use are state support and creation of a favourable environment for investment and business.

\section{Resources}

1. Z.O. Osmanova, Scientific Notes of the V.I.Vernadsky Crimean Federal University, 4 (2017)

2. A. A. Gorbacheva, A. E. Kormishin, Modern Economy Success, 1 (2019)

3. The official portal of the Federal State Statistics Service of the Russian Federation

4. Ministry of Economic Development of Russia, "Forecast of the long-term socioeconomic development of the Russian Federation for the period up to 2030", (2013)

5. N. N. Pasmurtseva, Bulletin of Rostov State Economic University, 3 (2019)

6. N. Pasmurtseva, Industry Competitiveness: Digitalization, Management, and Integration, 1 (2020)

7. E.V. Shirinkina, Bulletin of the Udmurt University. Econ. and Law, 1 (2019)

8. Program "Digital Economy of the Russian Federation", approved. By order of the Government of the Russian Federation No. 1632-r dated 28.07.2017

9. G.I. Abdrakhmanova, K.O. Vishnevsky, L.M. Gokhberg et al., Digital Economy: 2019: A Brief Statistical Compilation (2019)

10. Report "Digital Economy: Global Trends and Practice of Russian Business", 2017

11. N.R. Kelchevskaya, E.V. Shirinkina, Innovations in Mgmt., 18 (2018)

12. I. P. Dovby, N. V. Ionova, N. S. Dovby, Bulletin of SUSU. Economics and Mgmt., 1 (2019)

13. "Digital Champions" (2018) 